www.jmscr.igmpublication.org

Index Copernicus Value: 79.54

ISSN (e)-2347-176x ISSN (p) 2455-0450

crossrefDOI: https://dx.doi.org/10.18535/jmscr/v7i1.153

Original Article

\title{
A Study of Preoperative factors predicting difficult Laparoscopic Cholecystectomy
}

\author{
Authors \\ Dr Md. Masleh Uddin ${ }^{1}$, Dr Sanju Sharma ${ }^{2}$, Dr Radhika Raman ${ }^{3 *}$ \\ ${ }^{1}$ MS Student NMCH Patna \\ ${ }^{2}$ Assistant Professor Anaesthesia MGMMC Kishanganj \\ ${ }^{3}$ Associate Professor Gen Surgery NMCH Patna \\ *Corresponding Author \\ Dr Radhika Raman \\ Email: ramanradhika15@gmail.com
}

\section{Introduction}

Cholecystectomy is the most common elective procedure performed on hepato-biliary system. Laparoscopic cholecystectomy has become the gold standard for benign gallbladder disease in very short time ${ }^{1}$. Sometimes Laparoscopic cholecystectomy becomes difficult when there is congenital arterial, ductal or structural anamoly of gallbladder is present ${ }^{2}$. Acute inflammation with gangrenous gallbladder, dense adhesions, small, fibrotic, thick walled gall bladder, cholecystoenterocholic fistula will cause difficulty in performing Laparoscopic cholecystectomy. Other risk factors $^{3}$ like old age, male sex, obesity, clinical signs of acute cholecystitis, prior upper abdominal surgery, impacted stones, and pericholecystic fluid will further add to difficult Laparoscopic cholecystectomy. ${ }^{4}$

Preoperative prediction of conversion or difficulty atsurgery is an important aspect of planning Laparoscopic cholecystectomy. An accurate prediction may become necessaryfor counselling the patient and their attendants regarding conversion to open cholecystectomy. The surgeon may get indication so that he may accordingly schedule the time and team for surgery. Patients may be informed for longer hospitalisation and more intense post operative care. Hospital administration may manage their admission and bed vacancy efficiently.

\section{Objectives}

The objective of the study was to predict difficult Laparoscopic cholecystectomy and to establish relationship between the preoperative clinical and diagnostic evaluation.

\section{Material and Method}

A cross sectional study was conducted on 105 patients admitted for cholecystectomy from August 2015 to November 2017 in a government medical college of Patna, Bihar.

All patients with gallbladder stone disease admitted for cholecystectomy and who gave 
consent were included in the study. This study excluded patients with common bile duct stone disease, carcinoma of gallbladder, acute attack of cholecystectomy of more than 72 hours and the conversion due to equipment failure.

A written informed consent wastaken from the study participants after explaining the procedure. A predesigned, pretested schedule was prepared for all the study participants which included demographic details, history, clinical findings and investigations. The collected data was compiled on Microsoft Excel and data analysis was carried on SPSS version 16.0. Multivariate Analysis was carried out to find the predictors of difficult laparoscopic cholecystectomy.

All the cases were predicted to be easy, difficult or very difficult for Laparoscopic cholecystectomy based on preoperative history, clinical and ultrasonographic parameters. Causes of difficult laparoscopic cholecystectomy and conversion to open cholecystectomy were analysed preoperatively and postoperatively.

\section{Results}

Our study included 105 participants, out of which $40(38.1 \%)$ were difficult and rate of conversion was $3.8 \%$. One forth $(25.7 \%)$ of the study participants were in the age group of 21-30 years and majority $(86.7 \%)$ were females. $54.3 \%$ patients had history of hospitalization for acute attacks. (Table 1)

In our study there was no abdominal scar in $63.8 \%$ and infraumbilical scar in $35.2 \%$ of participants. The gall bladder was not palpable in $82.9 \%$ and the GB wall thickness of $\geq 4 \mathrm{~mm}$ was found in $11.4 \%$ of patients. Only $6.7 \%$ patients had pericholecystic collection and $42.9 \%$ had an impacted stone. In our study the age $>50$ years $(\mathrm{p}<0.000)$, male sex $(\mathrm{p}<0.000)$, history of hospitalization for acute cholecystitis $(\mathrm{p}<0.000)$, BMI $>27.5(p<0.002)$, abdominal scar $(\mathrm{p}<0.001)$, palpable GB $(\mathrm{p}<0.000)$, thickened GB wall $(\mathrm{p}<0.001)$ and pericholecystic collection $(\mathrm{p}<0.001)$ were found to be statistically significant predictors of difficult laparoscopic cholecystectomy. (Table 2)

Out of 105 patients, $59(56.2 \%)$ had a score of $0-5$ and 57 out of the 59 were found easy and 2 were difficult on laparoscopic cholecystectomy. 41 (39.1\%) out of 105 patients had score between 610 and 36 out of them were found difficult on laparoscopic cholecystectomy. (Table 3)

Table 1: Demographic Details of Study Participants

\begin{tabular}{|c|c|c|c|c|}
\hline $\begin{array}{l}\text { Demographic } \\
\text { Details }\end{array}$ & $\begin{array}{c}\text { No. of Participants } \\
(\%)\end{array}$ & $\begin{array}{l}\text { No. of difficult } \\
\text { cases }(\%)\end{array}$ & $\begin{array}{c}\text { No. of conversions } \\
(\%)\end{array}$ & $\begin{array}{c}\text { Rate of Conversion } \\
(\%)\end{array}$ \\
\hline \multicolumn{5}{|l|}{ Age (in Years) } \\
\hline $11-20$ & $10(9.5)$ & $0(0.0)$ & $0(0.0)$ & $0(0.0)$ \\
\hline $21-30$ & $27(25.7)$ & $5(4.8)$ & $0(0.0)$ & $0(0.0)$ \\
\hline $31-40$ & $24(22.9)$ & $9(8.6)$ & $1(0.9)$ & 4.2 \\
\hline $41-50$ & $24(22.9)$ & $13(12.4)$ & $1(0.9)$ & 4.2 \\
\hline $51-60$ & $15(14.3)$ & $9(8.6)$ & $2(1.9)$ & 13.3 \\
\hline $61-70$ & $05(4.7)$ & $4(3.8)$ & $0(0.0)$ & $0(0.0)$ \\
\hline \multicolumn{5}{|l|}{ Sex } \\
\hline Male & $14(13.3)$ & $10(9.5)$ & $2(1.9)$ & 14.3 \\
\hline Female & $91(86.7)$ & $30(28.6)$ & $2(1.9)$ & 2.2 \\
\hline \multicolumn{5}{|c|}{ History of Hospitalization } \\
\hline Yes & $57(54.3)$ & $39(37.1)$ & $4(3.8)$ & 7.0 \\
\hline No & $48(45.7)$ & $1(0.9)$ & $0(0.0)$ & $0(0.0)$ \\
\hline \multicolumn{5}{|l|}{ BMI } \\
\hline$<25$ & $30(28.6)$ & $6(5.7)$ & $0(0.0)$ & $0(0.0)$ \\
\hline $25-27.5$ & $45(42.9)$ & $19(18.1)$ & $0(0.0)$ & $0(0.0)$ \\
\hline$>27.5$ & $30(28.6)$ & $15(14.3)$ & $4(3.8)$ & 13.3 \\
\hline
\end{tabular}


Table 2: Multivariate Analysis of Intraoperative Outcome with risk factors

\begin{tabular}{|c|c|c|c|c|c|}
\hline \multirow[t]{3}{*}{ Risk Factors } & \multirow[t]{3}{*}{ Level } & \multicolumn{3}{|c|}{ Intraoperative Outcome } & \multirow[t]{3}{*}{ P Value } \\
\hline & & Easy & Difficult & \multirow{2}{*}{$\begin{array}{l}\text { Very Difficult } \\
\mathrm{N} \quad(\%)\end{array}$} & \\
\hline & & $(\%)$ & $(\%)$ & & \\
\hline \multirow[t]{2}{*}{ Age } & $\leq 50$ Years & $\begin{array}{ll}65 & (76.47) \\
\end{array}$ & $\begin{array}{ll}19 & (22.35) \\
\end{array}$ & $1 \quad(1.18)$ & \multirow[t]{2}{*}{$<0.000$} \\
\hline & $>50$ Years & $12(60.0)$ & $\begin{array}{ll}5 & (25.0) \\
\end{array}$ & $3 \quad(15)$ & \\
\hline \multirow[t]{2}{*}{ Sex } & Female & \begin{tabular}{|ll}
59 & $(64.84)$ \\
\end{tabular} & $30 \quad(32.97)$ & $2(2.20)$ & \multirow[t]{2}{*}{$<0.000$} \\
\hline & Male & $10(71.43)$ & $2 \quad(14.29)$ & $2(14.29)$ & \\
\hline \multirow{2}{*}{$\begin{array}{l}\text { History of } \\
\text { Hospitalization }\end{array}$} & No & $47 \quad(97.92)$ & $1 \quad(2.08)$ & $\begin{array}{ll}0 & (0.0) \\
\end{array}$ & \multirow[t]{2}{*}{$<0.000$} \\
\hline & Yes & $14 \quad(24.56)$ & $39 \quad(68.42)$ & $\begin{array}{ll}4(7.02) \\
\end{array}$ & \\
\hline \multirow[t]{3}{*}{ BMI } & $<25$ & $24(80)$ & $\begin{array}{ll}6 & (20) \\
\end{array}$ & $\begin{array}{ll}0 & (0.0) \\
\end{array}$ & \multirow[t]{3}{*}{0.002} \\
\hline & $25-27.5$ & $26 \quad(57.78)$ & $19 \quad(42.22)$ & $\begin{array}{ll}0 & (0.0) \\
\end{array}$ & \\
\hline & $>27.5$ & $\begin{array}{ll}11 & (36.67) \\
\end{array}$ & $\begin{array}{ll}15 & (50.0) \\
\end{array}$ & $4 \quad(13.33)$ & \\
\hline \multirow{3}{*}{ Abdominal Scar } & No & $46 \quad(68.66)$ & $21(31.34)$ & $\begin{array}{ll}0 & (0.0) \\
\end{array}$ & \multirow[t]{3}{*}{0.001} \\
\hline & Infraumbilical & $15 \quad(40.54)$ & $19 \quad(51.35)$ & $3 \quad(8.11)$ & \\
\hline & Supraumbilical & $\begin{array}{ll}0 & (0.0) \\
\end{array}$ & $\begin{array}{ll}0 & (0.0) \\
\end{array}$ & $1 \quad(100.0)$ & \\
\hline \multirow{2}{*}{$\begin{array}{ll}\text { Palpable } & \text { Gall } \\
\text { Bladder } & \\
\end{array}$} & No & $\begin{array}{ll}59 & (67.82) \\
\end{array}$ & $26 \quad(29.89)$ & $\begin{array}{ll}2 & (2.30) \\
\end{array}$ & \multirow[t]{2}{*}{$<0.000$} \\
\hline & Yes & $\begin{array}{ll}2 & (11.11) \\
\end{array}$ & $14 \quad(77.78)$ & $2 \quad(11.11)$ & \\
\hline \multirow{2}{*}{$\begin{array}{l}\text { Gall Bladder wall } \\
\text { thickness }\end{array}$} & $<4 \mathrm{~mm}$ & $\begin{array}{ll}58 & (62.37) \\
\end{array}$ & $\begin{array}{ll}34 & (36.56) \\
\end{array}$ & $1 \quad(1.08)$ & \multirow[t]{2}{*}{0.001} \\
\hline & $\geq 4 \mathrm{~mm}$ & $\begin{array}{ll}3 & (25) \\
\end{array}$ & (50) & $\begin{array}{ll}3 & (25) \\
\end{array}$ & \\
\hline \multirow{2}{*}{$\begin{array}{l}\text { Pericholecystic } \\
\text { Collection }\end{array}$} & No & $61 \quad(62.24)$ & $35 \quad(35.71)$ & $2 \quad(2.04)$ & \multirow[t]{2}{*}{0.001} \\
\hline & Yes & $\begin{array}{ll}0 & (0.0) \\
\end{array}$ & $5 \quad(71.43)$ & $2 \quad(28.57)$ & \\
\hline \multirow[t]{2}{*}{ Impacted stone } & No & $42 \quad(70.0)$ & 17 (28.33) & $(1.67)$ & \multirow[t]{2}{*}{0.093} \\
\hline & Yes & $19 \quad(42.22)$ & $23 \quad(51.11)$ & $3 \quad(6.67)$ & \\
\hline
\end{tabular}

Table 3: Relation between Preoperative Score and Outcome

\begin{tabular}{|l|c|c|c|c|}
\hline Pre-op Score & Easy (\%) & Difficult (\%) & Very Difficult (\%) & Total (\%) \\
\hline $0-5$ & $57(54.2)$ & $2(1.9)$ & $0(0.0)$ & $59(56.2)$ \\
\hline $6-10$ & $4(3.8)$ & $36(34.3)$ & $1(0.9)$ & $41(39.1)$ \\
\hline $11-15$ & $0(0.0)$ & $2(1.9)$ & $3(2.9)$ & $5(4.8)$ \\
\hline Total & $61(58.1)$ & $40(38.1)$ & $4(3.8)$ & \\
\hline
\end{tabular}

\section{Discussion}

In our study of 105 patients various preoperative parameters including age, sex, history of hospitalisation for acute attacks, previous upper abdominal surgery, obesity, increased leucocytosis, elevated hepatic enzymes, palpable gall bladder, USG findings like gallbladder wall thickness, CBD diameter, pericholecystic collection, stone impaction at the neck shows maximum correlation with difficult Laparoscopic cholecystectomy and/or conversion of Laparoscopic cholecystectomy to open cholecystectomy. This result is comparable to several other studies like Randhawa et al (2009) ${ }^{5}$ with conversion rate $1.3 \%$, Gupta $\mathrm{N}$ et al $(2013)^{6}$ $4.3 \%$, Vikalp Guptaet.al $(2017)^{7} 6 \%$. The universal accepted range of conversion is 2 $15 \%$.

The conversion rate was highest in the age group of $51-60$ years. In this study multivariate logistic analysis age $>50$ years was also found statistically significant predictor $(\mathrm{P}<0.0000)$ of conversion. Old age has been found to be a significant risk factor for difficult laparoscopic cholecystectomy and our finding is consistent with other studies. ${ }^{5,6,8}$ The male: female ratio was 1:6.5 in our study and the conversion rate was 6.5 times higher in male patients. This was similar to study by Genc V et $\mathrm{al}^{9}$ and Van der Steeg H.J.J et $\mathrm{al}^{10}$.

Patients have a linear correlation between previous history of hospitalisation due to acute cholecystitis and the difficulty level of Laparoscopic cholecystectomy. ${ }^{11}$ Each attack of cholecystitis increases the gallbladder wall thickness and the gallbladder becomes scarred and fibrosed. It further increases the adhesions at Calot's triangle. In this study out of 57 patients with H/O hospitalisation, 39 (68.4\%) were difficult and $4(7 \%)$ were very difficult which 
required open conversion and was found to be a statistically significant factor for prediction of difficult Laparoscopic Cholecystectomy ( $\mathrm{P}<$ 0.000). Among clinical parameters, abdominal scar was also found to be significant predictor in this study due to adhesions present between viscera or omentum and abdominal wall. There may be chances of injuries to these structures during various steps of laparoscopic surgery. The risk of conversion was reported to be higher. ${ }^{12}$ This study is in agreement with Karayiann et $\mathrm{al}^{13}$ (2004). This study also found the abdominal scar to be significant predictive factors of difficult laparoscopic cholecystectomy.

Obesity has been considered as a risk factor for laparoscopic cholecystectomy as observed by Rosen et al. ${ }^{14}$ Difficulties significantly increases as BMI increases more than 27.5. This is in agreement with Hussein A. et al. ${ }^{12}$ Certain studies claim that there was no difference in operating time, and length of hospitalisation. In our study BMI > 27.5, out of 30 patients 15 were difficult and $4(13,3 \%)$ were very difficult required conversion and it was found to be a significant factor $(\mathrm{P}<0.002)$

Palpable gallbladder is a clinical finding seen in mucocele or empyema or adhesions of gallbladder with omentum. In these cases it is difficult to catch the fundus and chance of spillage of content and stones in the peritoneal cavity is more. Few studies by Randhawa et $\mathrm{al}^{5}$, Gupta $\mathrm{N}^{6}$ and Agrawal et $\mathrm{al}^{8}$ found a significant intraoperative difficulty in obese patients. In this study it has also been found to be asignificant factor $(\mathrm{P}<0.000)$ on multivariate analysis.

Ultrasonographic significant findings are thickened gallbladder wall, stone impaction at neck, pericholecystic collection, short and wide cystic duct and may be due to recurrent inflammation. Gallbladder wall more than $3 \mathrm{~mm}$ is a clinical warning for laparoscopic surgeon for a difficult laparoscopic cholecystectomy. Stone impacted at neck poses some technical difficulties. Difficult dissection at Calot's triangle may cause bleeding from gallbladder bed, difficult application of clips in a wide cystic duct, CBD injury, tear of cystig artery, tear of gallbladder with spillage of bile and stones in peritoneal cavity. It was a significant predictor in previous studies $^{15}$ and in our study also. These various difficulties leading to operative time more than 90 minutes or conversion to open cholecystectomy were taken as difficult cases.

This study shows that preoperative scoring system can predict operative difficulty for laparoscopic cholecystectomy to a good extent. This system can also aid in recognition of cases where an open cholecystectomy should be considered and the patient counselled preoperatively.

\section{References}

1. Adnan Mehraj, Muhammad Ali Naqvi. Shizan Hamid Feroz, Haroon ur Rasheed. Laparoscopic cholecystectomy : An audit of 500 patients. J Ayub Med Coll, Abbottabad 2011;23:88-89

2. Singh K, Ohri A. Difficult laparoscopic cholecystectomy : A large series from north India. Ind. J Surg. 2006;68(4):205e8

3. Abdel Baki NA, Motawei MA, Soliman KE, et.al. Pre-operative prediction of difficult Laparoscopic cholecystectomy using clinical and ultrasonographic parameters. JMRI 2006;27(3):102e7.

4. Kama NA, Kologlu M, Doganayet.al. A risk score for conversion from laparoscopic to open cholecystectomy Am J Surg 2001;181:520e5.

5. Randhawa JS, Pujahari AK. Preoperative prediction of difficult Lapchole: A scoring method. Indian J Surg 2009;71:198-201.

6. Gupta N, Ranjan G, Arora MP, Goswami B, Chaudhary P. Validation of a scoring system to predict difficult laparoscopic cholecystectomy. Int J Surg 2013;11:1002-06.

7. Gupta V et al. Preoperative Prediction of difficult Laparoscopic CholecystectomyA scoring system. IJSR.2017 march; 6;13:1041-43. 
8. Agarwal N, Singh $\mathrm{S}$, Khichy $\mathrm{S}$. Preoperative prediction of Difficult Laparoscopic Cholecystectomy: A Scoring Method. Nigerian J of Surg. 2015; 21(2): 130-33.

9. Genc V, Sulaimanov M, Cipe G, Basceken S I, Gurel NEM, Aras N, Hazinedaroglu SM. What necessitates the conversion to open Cholecystectomy? A retrospective analysis of 5164 consecutive laparoscopic operations: Clinics. 2011; 66(3):417-20.

10. Vander Steeg HJJ et al. Risk factors for conversion during laparoscopic Cholecystectomy-experiences from a Scandinavian Journal of surgery 2011. 100:169-73.

11. Bouarfa L, Schneider A, Feussner H, Navab N, Lemek HU, Jonker PP, et al. Prediction of intraoperative complexity from preoperative patient data for laparoscopic Cholecystectomy. ArtifIntell Med 2011 Jul;52(3): 169-76.

12. Hussain A. Difficult laparoscopic cholecystectomy: current evidence and strategies of management. Surglaparosc Endosc Percutan Tech 2011;21(4);211-17.

13. Karayiann AJ, Polychronidi A, Perent S. Laparoscopic Cholecystectomy in patients with previous upper or lower GI surgery. Surgical Endoscopy 2004; 18:1097-1101.

14. Rosen M, Brody F, Posky J. Predictive factors for conversion of Laparoscopic Cholecystectomy. Am J Surg 2002; 184(3):254-8.

15. Nachnani J, Supe A. Pre-operative prediction of difficult Laparoscopic Cholecystectomy using clinical and ultrasonographic parameters. Indian J Gastroentrol 2005;24(1):16-18. 